РОЗДІЛ 1. ЗАГАЛЬНА ПЕДАГОГІКА ТА ІСТОРІЯ ПЕДАГОГІКИ

\author{
ІСТОРИКО-ПЕДАГОГІЧНА РЕТРОСПЕКТИВА У ВИКЛАДАННІ \\ IНОЗЕМНИХ МОВ У СЛОВАЧЧИНІ (1918-2018 рр.) \\ HISTORICAL AND PEDAGOGICAL RETROSPECTIVE \\ IN TEACHING FOREIGN LANGUAGES IN SLOVAKIA (1918-2018)
}

УДК 373.542

DOI https://doi.org/10.32843/2663$6085 / 2021 / 36.1$

\section{Годунко Л.В.,}

канд. пед. наук,

старший викладач англійської мови

Відокремленого структурного підрозділу

«Сарненський педагогічний фаховий

коледж Рівненського державного

гуманітарного університету»
Дослідження орієнтоване на минуле та сьогодення викладання іноземних мов на території Словаччини з 1918 до 2018 р. Воно містить огляд того, як було організоване викладання іноземних мов у цій галузі протягом ста років. У статті проаналізовано історичні передумови у вивченні іноземних мов у різних типах закладів освіти. Обгрунтовано актуальність вивчення та узагальнення зарубіжного досвіду у здійсненні послідовних рефоорм в іншомовній освіті. Дослідження ставить освітні ресрорми щодо викладання іноземних мов в історичну перспективу, що відображає зростаюче значення, яке надається викладанню іноземних мов національною політикою. Відзначено важливість прийняття значної кількості освітніх постанов, актів та положень, що сприяли успішному розвитку іншомовної освіти в країні. Викладання німецької мови здійснювалося поруч із грецькою та латиною у гімназіях у період із 1918 р. до Другої світової війни. Указано на вивчення російської мови з другого класу початкової школи як обов'язкової і другої сучасної іноземної мови з п'ятого класу як факультативної з 1950 по 1989 р. Акцентовано на зниженні домінуючої ролі російської мови як іноземної мови для вивчення в різних типах закладів освіти з 1989 р. Виявлено підвищений інтерес до вивчення англійської мови як обов'язкової іноземної мови та німецької, фрранцузької, іспанської, італійської мов як другої іноземної мови з 1989 р. Наголошено на особливостях перепідготовки вчителів іноземних мов через виконання програм міжнародних організацій для підвищення кваліфрікації вчителів. Установлено, що у Словаччині активне рефоормування розпочалося з Нової концепиії викладання та вивчення іноземних мов у початковій і середній школах (2007р.), яка відповідає Загальноєвропейським рекомендаціям з мовної освіти. Цей документ передбачає досягнення випускниками середніх шкіл рівня В1/В2 з першої іноземної і рівня A1/B1 з другої іноземної мови; збільшення кількості кваліфрікованих вчителів іноземної мови; інтенсивний розвиток мовної політики; розроблення нових навчальних програм та підручників.

Ключові слова: іноземні мови, викладання, навчання, розвиток, ресрормування.
The study focuses on the past and present of foreign language teaching in Slovakia from 1918 to 2018. It provides an overview of how foreign language teaching has been organized in this field for a hundred years. The article analyzes the historical preconditions in the study of foreign languages in different types of educational institutions. The relevance of studying and generalizing foreign experience in the implementation of successive reforms in foreign language education is substantiated. The study places educational reforms on foreign language teaching in a historical perspective, reflecting the growing importance given to foreign language teaching by national policy. The authors noted the importance of adopting a significant number of educational documents, acts and regulations that contributed to the successful development of foreign language education in the country. German was taught alongside with Greek and Latin in grammar schools from 1918 until World War II. The Russian language learning from the second grade of primary school as a compulsory language and the second modern foreign language from the fitth grade as an optional language from 1950 to 1989 is indicated. Emphasis has been placed on reducing the dominant role of Russian as a foreign language to study in various types of educational institutions since 1989. There has been a growing interest in learning English as a compulsory foreign language and German, French, Spanish, and Italian as a second foreign language since 1989. Emphasis is placed on the peculiarities of foreign language teachers retraining through the implementation of programs of international organizations for teacher training. It is established that in Slovakia active reforms began with the New Concept of teaching and learning foreign languages in primary and secondary schools (2007), which corresponds to the European Framework of References. This document provides for secondary school graduates to achieve level B1 / B2 in the first foreign language and A1 / B1 in a second foreign language; increasing the number of qualified foreign language teachers; intensive development of language policy; development of new curricula and textbooks.

Key words: foreign languages, teaching, learning, development, reforming.
Постановка проблеми в загальному вигляді. На сучасному етапі фрормування глобалізованого суспільства відчувається потреба в опануванні іноземних мов, які слугують засобом комунікації і засобом реалізації діалогу культур, розвитку взаєморозуміння та толерантності. Саме тому в Україні, яка зробила європейський вибір, важливим є вивчення, узагальнення та впровадження досвіду найближчих європейських сусідів у проведенні інтенсивних ресрорм у ссрері мовної та іншомовної освіти.

Словаччина-одназ країн-сусідів України-проводить успішні реформи мовної освіти і має значні досягнення на шляху оновлення ії̈ змісту. Важливою передумовою у дослідженні ресрорматорських 
змін із цієї ланки освіти є ретроспективний аналіз викладання іноземних мов у навчальних закладах країни: початковій, середній школах, а також процес підготовки вчителів іноземних мов.

Аналіз останніх досліджень і публікацій. В Україні вийшла друком низка статей та монографій, які стосуються досліджень сучасних тенденцій розвитку іншомовної освіти. Зокрема, у монограсрії М. Тадеєвої визначено лише основні напрями модернізації шкільної іншомовної освіти в країнах - членах Ради Європи [2]. Цінними для нас також є результати досліджень мовної освіти у працях словацьких лінгводидактів (3. Гадусова (Z. Gadusova) [6], Я. Гартанська (J. Hartanska) [6], 3. Кралова (Z. Kralova) [9], Г. Лойова (G. Lojova) [10], Е. Тандлічова (Е. Tandlichova) [12] та ін.).

Мета статті - проаналізувати історико-педагогічну ретроспективу викладання іноземних мов у Словаччині з метою впровадження позитивного досвіду в шкільну іншомовну освіту України, а також визначити специорічні особливості рефрормування процесу викладання іноземних мов у Словаччині з 1918 до 2018 р.

Виклад основного матеріалу. Після заснування незалежної Чехословацької держави 1918 р. у шкільну систему були внесені суттєві зміни: добудовано мережу початкових шкіл загальної базової освіти, збільшено кількість середніх шкіл та засновано нові університети, зокрема Університет Коменського в Братиславі 1919 р. До Другої світової війни чехословацька система освіти була однією з найбільш розвинених у світі.

У період між Першою і Другою світовими війнами в гімназіях поруч із латиною та грецькою мовою викладали принаймні одну сучасну мову, здебільшого це була німецька. Метою викладання іноземних мов було набуття учнями глибокого розуміння усного та письмового дискурсу шляхом теоретичного викладу та використання практичних тренувань, що включали читання, запам'ятовування нових слів та виконання усних та письмових вправ. Указ Словацької національної ради від 6 вересня 1944 р. «Про націоналізацію шкіл» перетворив усі школи на державні [9, с. 11].

Після Другої світової війни під тиском відносин із Радянським Союзом німецька мова перестала викладатися в початкових та середніх школах. Її замінила російська мова як єдина обов'язкова іноземна мова (викладання починалося з п'ятого класу початкової школи). Російська мова також стала обов'язковим предметом для випускних іспитів у середніх школах упродовж наступних сорока років. Інші іноземні мови викладалися лише в шкільних аматорських клубах або як необов'язкові предмети.

У лютому 1948 р. до влади прийшов комуністичний режим, який проводив освітні реформи, спрямовані на єдину школу, що відповідала б комуністичній ідеології та центральному контр- олю. Фактично ця система тривала до 1990 р. Викладання суворо контролювалося за допомогою навчальних програм, уніфрікованих підручників та регулярних відвідувань шкіл інспекторами.

Ресорма 1959 р. вперше запровадила в навчальну програму другу іноземну мову. Ії̈ викладали як необов'язковий предмет на післяобідніх заняттях у 7-9-х класах середньої школи. Наступна шкільна ресрорма 1961 р. збільшила кількість годин, які можна було б присвятити другій іноземній мові для учнів 9-11-х класів старшої школи. Метою викладання іноземних мов було навчити учнів читати та перекладати прості тексти та сорормувати у них основи усного спілкування [9, с. 11].

Слід зазначити, що з 60-х років минулого століття у школах із поглибленим вивченням іноземних мов із третього класу учнів навчали трьом іноземним мовам: англійській, німецькій та фрранцузькій. За даними Eurydice 2001 р., такі школи фрункціонують донині. Навчальні програми 1966 р. вже розмежовували практичні мовні навички та теоретичну лінгвістичну компетентність. Тенденція до політизації шкільної системи помітно зросла в 1970-х роках. Це був період так званої «нормалізації» після російського вторгнення до Чехословаччини в серпні 1968 р. Університети припинили підготовку викладачів сучасних мов, а кафредри іноземних мов були скасовані протягом 1970-х років. Єдина можливість вивчати сучасні мови була на факультетах мистецтв, де кількість прийнятих студентів була дуже обмежена [6].

У 1960-1970-х роках словацьке педагогічне видавництво у Празі розпочало видавати підручники іноземних мов, які на відміну від тих, що використовувалися, намагалися відображати директиви затверджених навчальних програм. 1970-ті та 1990-ті роки були дуже продуктивними періодами для реформ, що стосуються викладання іноземних мов. Ключовою реформою 1970-х років став проєкт під назвою «Подальший розвиток чехословацької освітньої системи» (1976р.), метою якого було оновлення навчального змісту шляхом переходу від попередніх методів навчання, орієнтованих на механічне відтворення навчального матеріалу та розвиток творчості учнів. Цей документ став початковою точкою для групи експертів Педагогічного інституту в Братиславі для розроблення нових навчальних програм, спрямованих на розвиток комунікативних навичок для використання в гімназії [9, с. 12].

Однак викладання іноземних мов здебільшого залишалося на рівні формальних указівок учителя 3 акцентом на порівняльне граматичне викладання та запам'ятовування нових слів. Навчання проводилося у переповнених класах із незначною можливістю для індивідуальної роботи, крім відповідей на запитання та читання вголос коротких уривків, та незначною наочністю. Використовувана мето- 
дологія поєднувала граматико-перекладні методи, методи читання 3 великим обсягом роботи для запам'ятовування, виправлення помилок та перевірки знань. Популяризація лінгвістичної та комунікативної компетентності шляхом використання заданих тем для мовлення навряд чи розглядалася як необхідна частина навчального процесу.

Удосконалення володіння іноземною мовою в природному середовищі було тоді можливим лише для вчителів російської мови. Як правило, їх направляли до університету-партнера в Радянський Союз на два місяці. Для некваліфікованих учителів російської мови в Чехословаччині була впроваджена програма перекваліфрікації на вітчизняних фракультетах із восьмитижневим перебуванням у Радянському Союзі. Окрім того, вчителі російської мови могли провести один семестр у радянському вищому навчальному закладі. Із 80-х років це стажування стало обов'язковим відповідно до нової Концепції викладання іноземних мов у чехословацьких школах.

Із 1948 до 1989 р. у Чехословаччині було значно обмежено низку основних прав людини, наприклад право на політичну та релігійну свободу, право на свободу слова та свободу освіти і право на збори. Учителі так званих західних мов найбільше постраждали від обмежень вільного пересування, вони не мали ні дозволу на поїздки, ні доступу до іноземної валюти, не мали можливості практикувати свої знання іноземної мови в реальних комунікативних ситуаціях і покладалися виключно на теоретичні джерела. Відсутність безпосереднього контакту з носіями мови проявилася у відсутності комунікативних навичок. Покоління, виховане в епоху комунізму, все ще страждає від наслідків цієї «неграмотності другої мови». Намагаючись контролювати «проникнення буржуазної ідеології», радіоканали західної мови були обмежені, а людей, спійманих під час прослуховування, переслідували. Окрім того, фрільми із західних країн не отримували субтитрів, але їх дублювали чеською чи словацькою мовою, позбавляючи вчителів можливості слухати живу мову. Тільки для російської мови на радіо існували мовні курси, які проводили носії російської мови [11, с. 188].

Одночасно було організовано величезну кількість заочних курсів. Варто згадати про так звані народні курси російської мови. Для вчителів російської мови виходили різні лінгвістичні та дидактичні журнали, спеціалізовані двомовні словники та підручники. Для учнів, які бажали вивчати російську мову, були організовані літні табори, які відвідували радянські діти того самого віку та їхні вчителі. Починаючи 31959 р. щорічно проводилися конкурс декламаторів під назвою «Меморіал О. Пушкіна» та російськомовна олімпіада.

Викладання та вивчення англійської або будьякої іншої західної мови було непростою справою.
Ресурсів бракувало: книг англійською мовою та підручників англійською мовою було мало, не кажучи вже про аудіо- та відеоматеріали. Інші матеріали, опубліковані на місцях, навряд чи були доступні, а в суворі періоди комунізму були заборонені. Підручники того періоду дотримувалися граматикоперекладного методу з однаковою структурою в кожному розділі, а текст необхідно перекладати та виконувати граматичні вправи.

Оксамитова, або Ніжна, революція 1989 р. була ненасильницьким переходом влади в Чехословаччині. Закінчився сорок один рік комуністичного правління, і було розпочато перетворення на парламентсько-демократичну республіку. Ці соціально-політичні події призвели до значних змін у багатьох аспектах життя. В освітній сорері однією 3 найбільш вражаючих змін став раптовий бум викладання та вивчення західних мов, особливо англійської, адже до 1989 р. вивчення «капіталістичних» мов було обмеженим.

У результаті цих соціально-політичних змін російська мова втратила своє панівне становище. Тепер учні початкових та середніх шкіл отримали можливість вибору з низки мов: окрім російської, були англійська, німецька, фрранцузька, іспанська та італійська. Із 1990 р. почали відкриватися загальні середні школи, що пропонували двомовну освіту, були створені двомовні гімназії, що пропонували для вивчення англійську, німецьку, фрранцузьку, італійську та іспанську мови. Безліч приватних мовних шкіл зросло в 1990-х роках, але багато з них працювали без достатнього контролю якості [5].

Підготовку вчителів англійської мови 1989 р. здійснювали лише два фракультети - у Братиславі та Прешові. На рубежі століття було створено дванадцять фракультетів підготовки вчителів англійської мови (Гадусова, Хартанська, 2002), із 1990-х років збільшилася й кількість програм підготовки вчителів у Словаччині. Запропонована навчальна програма суттєво змінилася, відображає нові вимоги до методології викладання. Словаччина потребувала 3 тис викладачів англійської мови, але їх було менше 2 тис. Із метою задоволення попиту на викладачів мови на обмежений перехідний період були укладені навчальні програми на рівні, еквівалентному університетському ступеню. Міністерство освіти ухвалило нову постанову, яка існувала до 2000 р., даючи змогу вчителям інших кваліфрікацій також викладати іноземні мови за умови, що ті складуть спеціальний іспит, щоб засвідчити своє володіння мовою [5].

Для збільшення кількості кваліфікованих учителів англійської мови за найкоротший час було створено, зокрема, програми перепідготовки колишніх учителів російської мови на англійську мову. Це стосувалося як учителів, які мають лише іспит на матуріту (середня школа), так і вчителів інших предметів, навчальне навантаження 
яких було доповнене уроками іноземної мови. У 1992-1997 рр. за сприяння Європейського Союзу в рамках програми PHARE були запроваджені прискорені 4-річні програми з акцентом на практичні мови та навички викладання в деяких педагогічних коледжах. Носіїв англійської мови часто наймали викладачами англійської мови, вважаючи, що їх володіння англійською мовою компенсує їхню некомпетентність як викладачів.

У той період іноземні мови викладали за допомогою підручників, виданих за кордоном, а підготовка вчителів була передана в різні інститути, такі як Британська Рада, Інформаційна служба США, Фонд Фулбрайта, Інститут Гете або Французький інститут. Не можна недооцінювати підтримку 3 боку іноземних посольств у цьому питанні. Таким чином, з 1990 р. неурядова та некомерційна Словацька академічна інфрормаційна агенція (SAIA) та Словацька академічна асоціація міжнародного співробітництва (SAAIC) сприяють інтерналізації освіти та науки у Словаччині за допомогою своїх різноманітних програм та послуг.

Варто зазначити, що такі заклади підготували місцевих учителів, запросили викладачів 3-за кордону (через різні організації, такі як «Корпус Миру», «Східноєвропейське партнерство», «Освіта для демократії»), щоб зробити свій внесок у новий міжкультурний досвід країни, створили ресурсні центри та бібліотеки (наприклад, центри Info USA), підготували навчальні матеріали та організували освітні курси вчителів за кордоном (наприклад, Схема контактів викладання англійської мови (ELTECS) в рамках Британської Ради). Одну з успішних навчальних програм для вчителів англійської мови, які працюють, реалізували регіональні навчальні центри протягом шести курсів на рік, де лекторами були носії англійської мови. За допомогою Європейського соціального фронду реалізовано низку проєктів із підготовки вчителів. У Словаччині Національний інститут освіти запропонував учителям початкових класів восьмисеместровий курс на основі національної навчальної програми для досягнення рівня В2 цільовою мовою в період із 2008 до 2013 р. [3].

Із 1989 р. більшість учителів відмовлялася продовжувати користуватися офріційно затвердженими чехословацькими підручниками іпочала все частіше використовувати підручники, видані за кордоном. Іноземні видавці через підручники привабливого формату швидко утвердилися на новоствореному ринку і часто проводили рекламні семінари для вчителів іноземних мов. Пізніше почали наголошувати на необхідності «домашніх» підручників, спеціально пристосованих до потреб носіїв словацької мови, які усунули б негативний вплив рідної мови під час вивчення іноземної мови. Спільні видавничі проєкти місцевих авторів та носіїв англійської мови виявилися дуже ефективними у цьому контексті.
Міністерство освіти попросило групу експертів оцінити та рекомендувати найбільш відповідні підручники англійської мови для шкіл, щоб уникнути плутанини на книжковому ринку [6].

Мовні асоціації, що займаються єдиною іноземною мовою, першими вказали на необхідність інновацій та систематизації у навчанні вчителів іноземних мов. Як Асоціація викладачів англійської мови Чеської Республіки, створена 1991 р., так і Асоціація викладачів англійської мови Словацької Республіки, створена 1992 р., стали членами Міжнародної асоціації викладачів англійської мови як іноземної (IATEFL), що базуються в Британії з початку 1990-х років. Нині професійна асоціація вчителів EFL (Словацька спілка вчителів англійської мови), співробітник IATEFL, разом зі Словацькою асоціацією 3 вивчення англійської мови (SKASE), членом Європейського товариства 3 вивчення англійської мови (ESSE), сприяють дослідженню та освіті в галузі англійської мови та літератури у Словаччині.

Радикальні зміни у словацькому суспільстві після 1989 р., створення незалежної Словацької Республіки 1 січня 1993 р. та вступ країни до Європейського Союзу 1 травня 2004 р. також вимагали змін до сучасної шкільної системи, включаючи інновації у змісті освіти викладання іноземних мов. По-перше, Лісабонська конвенція про визнання, підписана в Лісабоні 11 квітня 1997 р., підтримувала зближення європейських вимог до освіти шляхом визнання задокументованих компетентностей, знань та навичок. Словацькі вчителі закликали до більш об'єктивного оцінювання вивчення іноземних мов, і 1997 р. Словацька асоціація викладачів англійської мови (SAUA/SATE) розпочала роботу над новим проєктом Maturita y співпраці з Британською Радою у Словаччині [6].

Слід наголосити, що Загальноєвропейські рекомендації з мовної освіти: вивчення, викладання, оцінювання (ЗЄР) були опубліковані Відділом мовної політики Ради Європи 2001 р. після тривалого періоду досліджень та пілотних проєктів, що тривали з 1993 до 1999 р. Основна ідея проєкту полягала у сприянні взаємному визнанню кваліфікацій, забезпеченню прозорої, послідовної та всеохоплюючої основи для розроблення навчальних матеріалів та оцінки знань іноземної мови. ЗЄР відіграли важливу роль у змінах, що відбулися в країнах Центральної та Східної Європи з моменту їх уведення. У Словаччині вплив цього документа негайно відобразився в новій програмі англійської мови, що стосується загальних референтних рівнів, із метою встановлення цілей, комунікативних компетентностей (лінгвістичної, соціолінгвістичної та прагматичної), а також для підкреслення особистіснодіяльнісного підходу у навчанні, а не накопичення знань у викладанні іноземних мов [3]. 
Одним із ключових елементів Програми тисячоліття - Національної педагогічної та освітньої програми Словацької Республіки на наступні 15-20 років (2001р.) було розроблення основ викладання іноземних мов. Основним напрямом нової «Концепції викладання іноземних мов у початковій та середній школі» (2007р.) було надання підтримки створення полікультурного європейського суспільства та фрормування компетентності у володінні щонайменше двома іноземними мовами. Обов'язкове навчання першої іноземної мови було перенесено на третій рік початкової школи, а другої іноземної мови - на п'ятий, збільшено кількість годин на вивчення. Метадо закінчення середньої школи учні мають досягти комунікативної компетентності на рівні В1/B2 (як це визначено $3 € Р$ ) для першої іноземної мови та рівня А2/B1 для другої іноземної мови [1; 4].

22 травня 2008 р. Словаччина ухвалила новий шкільний закон, інтегруючи свою систему освіти в європейські рамки. Він містить національну освітню програму, яка служить обов'язковим документом для укладання будь-яких шкільних освітніх програм. Ця навчальна реформа мовної освіти повинна покласти край чинному різноманіттю планів навчання та поліпшити якість викладання іноземних мов. За вихідну точку береться положення Європейської Комісії щодо ефективного навчання мовам у ранньому віці, оскільки саме тоді фрормуються ключові установки на інші мови та культури та закладаються основи для подальшого засвоєння мови [9].

Документ «Концепція викладання іноземних мов у початковій та середній школах» (2007р.) натякає на кілька актуальних проблем у галузі викладання іноземних мов, зокрема йдеться про значний відсоток некваліфікованих викладачів, високий ступінь коливань серед викладачів та низький інтерес нових випускників шкіл до педагогічної професії.

Насторожує те, що лише невеликий відсоток кваліфікованих випускників педагогічних чи мистецьких фракультетів хочуть працювати у державній школі. Більшість студентів, які закінчили іноземні фракультети, віддає перевагу працевлаштуванню у приватних школах (із більшою оплатою праці) або у компаніях, які шукають спеціалістів зі знанням іноземних мов. Багато обдарованих та освічених молодих людей шукають роботу за кордоном. Нинішня несприятлива ситуація зумовлена не лише відсутністю фрінансових засобів, щоб утримати вчителів від міграції на інші, більш прибуткові робочі місця в бізнесі, банківській справі чи туризмі, а й недостатніми матеріально-технічними ресурсами в школах для викладання іноземних мов. Із чинних документів, а також інтерв'ю 3 батьками учнів початкової та середньої шкіл стає зрозуміло, що побутує загальне невдоволення викладанням іноземних мов, пов'язане, головним чином, із тим, що багато вчителів не мають права викладати іноземну мову, переважно англійську. Ці вчителі стикаються з перешкодами у спілкуванні, вони легко роблять граматичні помилки у своїх висловлюваннях, а їхня вимова часто $€$ недосконалою, і все це незважаючи на те, що сьогодні вчителі навчені застосовувати нові методології, концентруючись більше на мові як засобі спілкування, а не просто за правилами.

Опитування Британської Ради у Словаччині 2014 р. серед учителів англійської мови показує, що вони оцінюють умови викладання англійської мови у Словаччині як незадовільні. Найбільш чітко (95\% респондентів) відчули відсутність структури для додаткового підвищення кваліфікації та відсутність можливостей для мовного перебування за кордоном. Оскільки ці потреби недостатньо задовольняються, лише 17-21\% опитаних учителів кажуть, що вони почуваються повністю впевнено у володінні англійською мовою. Що стосується технічних ресурсів, то більшість респондентів (93\%) уважає відсутність інтегрованих навчальних матеріалів (дидактичний та цифрровий зміст як додаток до підручників) головним недоліком. Більшість цих висновків ідентичні даним 3 інших європейських країн, де така сама потреба відчувається у кваліфікованих учителях у початкових школах, у вищих стандартах підготовки вчителів та в додаткових курсах обслуговування для вчителів іноземних мов для всіх типів шкіл.

Результатом наявності в школах неквалісрікованих учителів є, звичайно, низький рівень компетентності іноземних мов в учнів. У недавньому тесті, проведеному серед вибірки учнів 8-го та 9-го класів, середній рівень успішності з іноземної мови становив лише $40 \%$. Цей фракт повинен дати чіткий сигнал про необхідність підвищення якості та ефективності викладання іноземних мов, починаючи з підвищення рівня кваліфрікації іноземних мов рівня А2 ЗЄР для вчителів початкових шкіл першого класу з акцентом на комунікативній компетентності (бесіда, діалог, індивідуальне усне спілкування) та 3 дидактики викладання іноземних мов для цільової групи учнів. Іншим важливим елементом, наприклад у рамках навчання впродовж життя, має бути забезпечення професійної мобільності серед учителів за допомогою мовних курсів за кордоном.

Висновки. Ретроспективний аналіз ресрормування процесу навчання іноземних мов із 1918 по 2018 р. у словацьких школах дає змогу визначити такі основні результати, які були досягнуті в ході здійснення послідовних реформ в іншомовній освіті Словаччини:

1. Обов'язкове вивчення іноземних мов у різних закладах освіти: початкових та середніх школах, а також університетах.

2. Прийняття значної кількості освітніх постанов, актів та положень, що сприяли успішному розвитку іншомовної освіти в країні. 
3. Викладання німецької мови поруч із грецькою та латиною у гімназіях у період із 1918 р. до Другої світової війни.

4. Вивчення російської мови з другого класу початкової школи як обов'язкової і другої сучасної іноземної мови з п'ятого класу як фракультативної з 1950 по 1989 р.

5. Поступове зниження домінуючої ролі російської мови як іноземної мови для вивчення в різних типах закладів освіти з 1989 р.

6. Підвищений інтерес до вивчення англійської мови як обов'язкової іноземної мови та німецької, фрранцузької, іспанської, італійської мов як другої іноземної мови з 1989 р.

7. Тенденція до збільшення годин, відведених на вивчення іноземних мов у початкових та середніх школах як основного навчального предмета, так і фракультативного.

8. Упровадження програм перепідготовки вчителів російської мови на викладання інших іноземних мов за допомогою міжнародних волонтерських організацій, таких як «Корпус Миру», «Освіта для демократії», через відсутність висококваліфікованих учителів сучасних іноземних мов.

9. Виконання програм Британської ради щодо підвищення кваліфікації вчителів іноземних мов.

10. Досягнення учнями комунікативної компетентності на рівні В1/В2 для першої іноземної мови та рівня A2/B1 для другої іноземної мови до закінчення середньої школи відповідно до ЗЄР.

11. Обов'язкове вивчення першої іноземної мови з третього класу початкової школи та другої іноземної мови 3 п'ятого класу середньої школи відповідно до Концепції викладання іноземних мов 2007 р.

\section{БІБЛІОГРАФІЧНИЙ СПИСОК:}

1. Загальноєвропейські рекомендації 3 мовної освіти: вивчення, викладання, оцінювання / Рада 3 питань співпраці в галузі культури. Комітет з освіти. Відділ сучасних мов ; за наук. ред. С.Ю. Ніколаєвої. Київ : Ленвіт, 2003. 273 с.
2. Тадеєва М.І. Розвиток сучасної шкільної іншомовної освіти в країнах - членах Ради Європи:монографрія.Тернопіль:Навчальнакнига,Богдан, 2010. 432 c.

3. Beresova J. The Impact of the Common European Framework of Reference on Teaching and Testing in Central and Eastern European Context. Synergies Europe. 2011. Vol. 6. P. 177-190.

4. Common European Framework of Reference for Languages: Learning, Teaching, Assessment / ed. M. Milanovic. Cambridge: Cambridge University Press, 2001. 276 p.

5. Foreign Language Teaching in Schools in Europe. Situation in Slovakia. Report drafted by Eurydice Unit. Bratislava : Slovak Academic Association for International Cooperation, 2001. P. 2-21.

6. Gaduŝová Z., Hartanska J. Teaching English in Slovakia: Past, Present and Future. Revista de Filologia y su Didactica. 2002. № 25. P. 225-253.

7. Hudson B., Zgaga B. Teacher education policy in Europe. A voice of higher education institutions. Monographs on Journal of research in teacher education. Umea : University of Umea, 2008. P. 17-42.

8. The Training of teachers of a Foreign Language: Developments in Europe / M. Kelly et al. A Report to the European Commission Directorate General for Education and Culture. Southampton : University of Southampton. 2004. P. 29-44.

9. Kralova Zdena. Teaching foreign languages in Slovakia (1918-2018). XLinguae, Volume 11, Issue 4, October 2018. P. 11-21.

10. Lojova G. Humanizing English language teaching in Slovakia. X Lingual journal. 2016. № 4. Vol. 9. P. 30-35.

11. Medgyes P. Innovative second language education in Central and Eastern Europe. Encyclopedia of Language and Education, Volume 4: Second Language Education. Dordrecht: Kluwer Academic Publishers, P. 187-196.

12. Tandlichova E. Looking at some innovative methods in the new conception of foreign languaage teaching at primary schools. In International Conference: ELT in Primary Education. Bratislava, 2008. P. 10-14. 